\title{
Monetary Policy Rule and its Performance under Inflation Targeting in Thailand
}

\author{
Hiroyuki Taguchi ${ }^{1}$ ' \\ Mesa Wanasilp \\ 1., Saitama University, Japan \\ Email:tagusava0710@s3.wh.qit.ne.jp Tel:819080551562
}

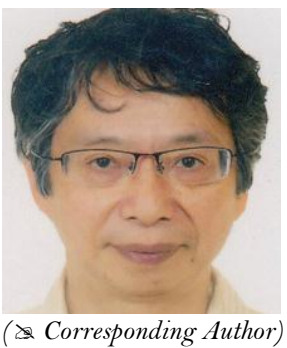

\begin{abstract}
This article reviews the Thailand monetary policy rule and its performance under the adoption of inflation targeting regime since 2000 . The study estimates the policy reaction function to see if the inflation targeting has been linked with an inflation-responsive monetary policy rule, and investigates whether the monetary policy rule would actually have its transmission effect on inflation, through tracing the impulse responses of inflation rate to monetary policy shocks. The main findings are as follows. The estimation outcomes of the policy reaction function show that the Thailand monetary policy rule is characterized as an inflation- and exchange-rate- responsive rule with forward-looking manner, which is countercyclical against inflation in the long run, but is accompanied with slow adjustment toward a target policy rate. The impulse response analyses imply that the Thailand monetary policy has only a marginal transmission effect on inflation probably due to the slow adjustment of policy rate.
\end{abstract}

Keywords: Monetary policy rule, Inflation targeting, The Bank of Thailand.

JEL Classification: E52, E58, O53.

Citation | Hiroyuki Taguchi; Mesa Wanasilp (2018). Monetary Policy Rule and its Performance under Inflation Targeting in Thailand. Asian Journal of Economics and Empirical Research, 5(1): 19-28.

History:

Received. 13 January 9018

Received: 13 January 2018

Revised: 24 January 2018

Accepted: 26 January 2018

Published: 30 January 2018

Licensed: This work is licensed under a Creative Commons

Attribution 3.0 License (cc)

Publisher:Asian Online Journal Publishing Group
Contribution/Acknowledgement: Both authors contributed to the conception and design of the study.

Funding: This study received no specific financial support

Competing Interests: The authors declare that they have no conflict of interests.

Transparency: The authors confirm that the manuscript is an honest, accurate, and transparent account of the study was reported; that no vital features of the study have been omitted; and that any discrepancies from the study as planned have been explained.

Ethical: This study follows all ethical practices during writing.

\section{Contents}

1. Introduction 20

2. Development of Monetary Policy Framework in Thailand 21

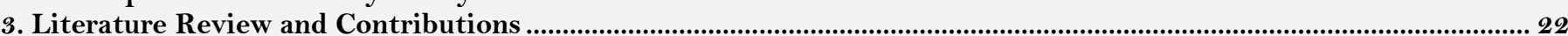

4. Empirical Analyses

5. Concluding Remarks 27

References 


\section{Introduction}

The Bank of Thailand has adopted "inflation targeting" as its monetary policy framework since May $2000 .{ }^{1}$ The background behind introducing inflation targeting lies in the currency crisis named "Tom Yum Goong Crisis" in July 1997. In this crisis Thailand abandoned pegged currency regime and switched to floating exchange rate system. Then it became necessary for the authority to identify a new policy anchor with a main objective of maintaining price stability. As Mishkin (2000) argued, inflation targeting has become an alternative nominal anchor to stabilize inflation instead of pegged currency regime.

The question then arises on how we can evaluate the inflation target that has been operated for around two decades since its adoption in Thailand. In general, there seems to be a consensus in academic literature and policy discussions that inflation targeting has so far been successful to stabilize inflation in advanced economies with their long histories of its adoption since the 1990s (e.g. (Mishkin and Posen, 1998; Mishkin and Schmidt-Hebbel, 2007)). As far as emerging market economies including Thailand are concerned, however, there have been rather less evidence to support the performance of inflation targeting due to their relatively shorter histories of its adoption and to some difficulties in its management.

The difficulties that emerging market economies have faced in operating their inflation targeting might come from exchange rate fluctuations for the following senses. First, inflation targeting can work well only when monetary autonomy is secured under floating exchange rate regime with capital mobility. Emerging market economies have, however, the problem of a "fear of floating", as suggested by Calvo and Reinhart (2002). It comes from a lack of confidence in currency value, especially given that their external debt is primarily denominated in US dollars. Their efforts to avoid exchange rate volatility prevent their monetary authorities from concentrating fully on inflation targeting. Second, as Eichengreen (2002) argued, exchange rate fluctuation itself has large influence on domestic prices through the "pass-through" effect in small, open economies. It makes it difficult for the monetary authorities to control inflation and to perform inflation targeting well. There is, however, a counterargument against the pass-through effect on inflation targeting. Gagnon and Ihrig (2004) argued that an inflation targeting framework reduces the pass-through effect, in the sense that domestic agents are less inclined to change prices in response to a given exchange rate shock under the strong commitment of the monetary authority to price stability.

Another possible difficulty for inflation targeting management in emerging market economies is the lack of credibility of the central bank capacity. It might come from arbitrary policy reactions accompanied with unreliable inflation forecasting by the central bank as well as the economic uncertainty and volatility. As long as agents do not believe that the monetary authority will be successful in achieving the inflation target, it will be difficult for inflation targeting to have any significant impact on the expectations and behavior of the private sector with respect to wage and pricing contracts. As Eichengreen (2002) emphasized, the lack of credibility would thus lessen inflation targeting performance.

Some studies, among the limited literature, have assessed inflation targeting in emerging market economies as "conditional" success. For example, Mishkin (2000;2004) argued that the success of inflation targeting could not be solely attributed to the actions of the central bank, and that supportive policies such as the absence of large fiscal deficits and rigorous regulation and supervision of the financial sector were crucial to its success. Lin and Ye (2009) also noted that the performance of inflation targeting could be affected by a country's characteristics such as the government's fiscal position, the central bank's desire to limit movements of the exchange rate and its willingness to meet the preconditions of policy adoption. Ito and Hayashi (2004) presented the following two recommendations on inflation targeting management, considering the characteristics of emerging market economies: 1) emerging market countries should set an inflation with target central rate slightly higher and with a target range slightly wider than a typical advanced country; (2) small, open economies may pursue both an inflation target range and an implicit basket band in exchange rate regime, as both targets are expressed in a range (the targets work as the source of stability in expectations, while the ranges allow some flexibility).

Thailand is not an exception in facing the aforementioned difficulties and conditional success in inflation targeting operation as one of emerging market economies. This article, in this context, reviews the monetary policy rule and its performance under inflation targeting framework focusing on Thailand. The study first estimates the policy reaction function to see if the adoption of inflation targeting has been linked with a monetary policy rule emphasizing on inflation stabilization. The study then investigates further whether the monetary policy rule would actually have its transmission effect on inflation, through tracing the impulse responses of inflation rate to monetary policy shocks in vector autoregressive (VAR) and structural VAR (SVAR) models.

The rest of the paper is structured as follows. Section 2 describes the historical development of monetary policy framework in Thailand. Section 3 reviews previous studies on the assessment of Thailand monetary policies and clarifies this paper's contribution. Section 4 conducts the empirical analyses, describing the data, the methodology, and the estimation results and their interpretations. Section 4 summarizes and concludes. 


\section{Development of Monetary Policy Framework in Thailand}

This section first describes the short history of the monetary policy framework after the second World War in Thailand, and then reviews the progress in inflation targeting setting since May 2000. ${ }^{2}$

The long-term development of the monetary policy framework in Thailand can be divided into the following three periods. The first is the period of pegged exchange rate regime from the second World War to June 1997. Under this regime, The value of local currency named "bath" was pegged either to gold, a major currency, or a basket of currencies. The second is the period of monetary targeting regime from July 1997 to May 2000. After the adoption of the floating exchange rate system on July 2, 1997, under the financial assistance program by the International Monetary Fund (IMF) during the crisis time, the Bank of Thailand targeted domestic money supply in such a way that the Bank set the daily and quarterly monetary base targets to stabilize financial markets. The third is the period of inflation targeting regime from May 2000 to present. Since the relationship between money supply and output growth became less stable over time after the financial crisis, the Bank adopted inflation targeting instead of monetary targeting in May 2000, together with the exit of the IMF program. At the same time, the Bank introduced the policy rate as an operational instrument for managing inflation targeting, so that the policy rate can affect real economy through transmission channels.

The Bank of Japan has upgraded the framework of inflation targeting since its adoption in the following way (the process is displayed in Figure 1). At the initial stage from May 2000 to August 2009, the core-inflation targetrange at between 0.0-3.5 percent was set based on the income ability of various groups of people and on the consistency with inflation of Thailand's trading partners for keeping price competitiveness. The "core" inflation is expressed by the year-on-year percentage change in the Consumer Price Index (CPI) that excludes fresh food and energy prices. The rationale for excluding these prices is that they are highly volatile in the short run as a result of factors beyond the control of monetary policy. The range target helps cushion temporary economic shocks and minimize the need for the authority to adjust monetary policy stances frequently. The core inflation rate had been assessed by not monthly but quarterly average to avoid the indicator's volatility.

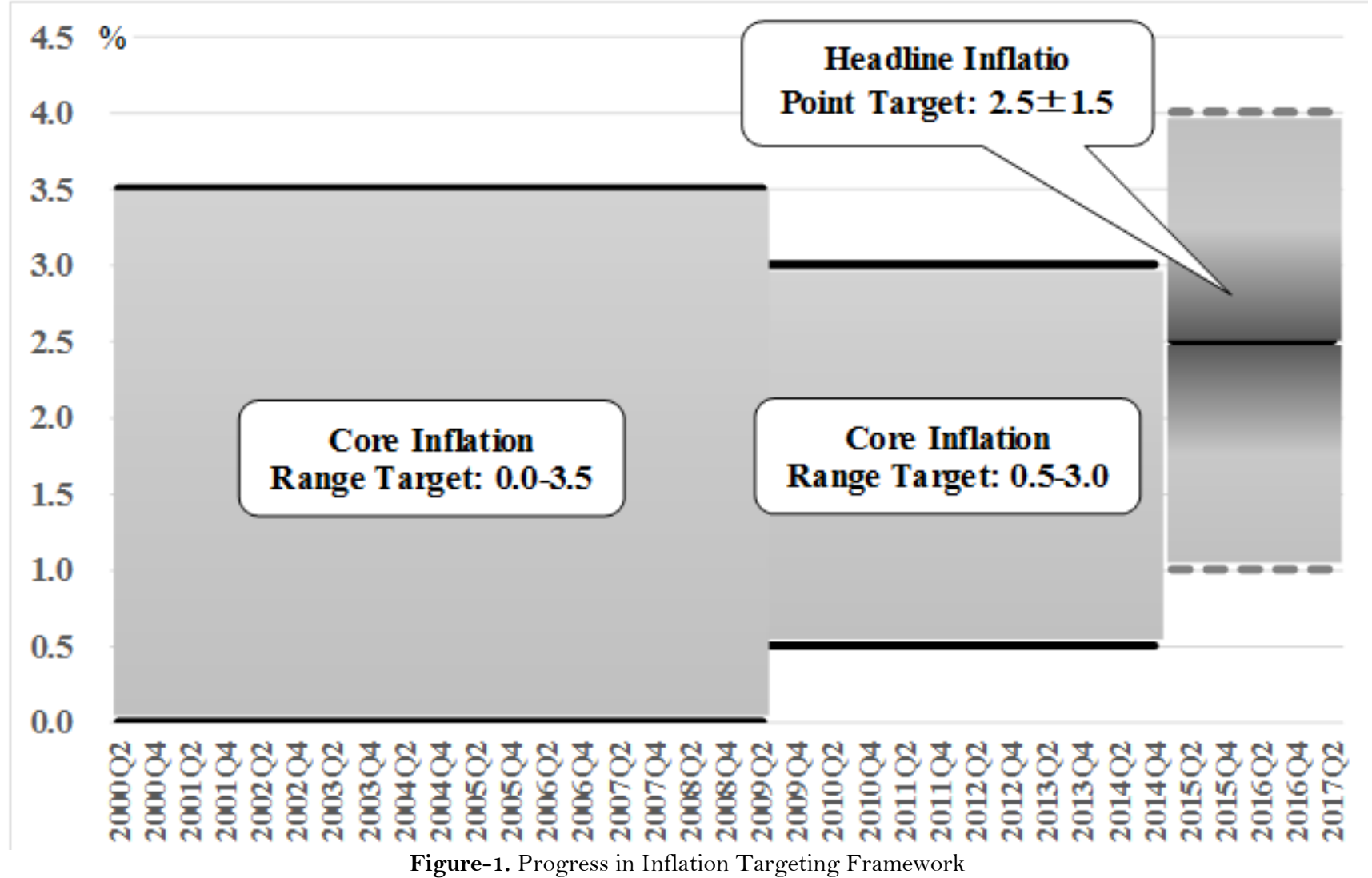

Source: Author's description based on the website of the Bank of Thailand

The second stage from September 2009 to January 2015 narrowed the target range from 0.0-3.5 percent to 0.53.0 percent. The lower bound of the range was adjusted upwards by 0.5 percent to reduce the probability of deflation, while the upper bound was lowered by the same amount to signal no change in the overall monetary policy stance.

At the current phase from January 2015 to present, the new target has been set for the annual average of headline inflation to be at 2.5 percent with a tolerance band of \pm 1.5 percent. The rationale of adopting "headline" inflation instead of "core" inflation is that the headline inflation is better in reflecting more accurately the change in the cost of living, since it captures changes in prices of all goods and services in the CPI basket. Changing from the target range of 0.5 -3.0 percent to point target at 2.5 percent with a band of \pm 1.5 percent gives a clearer policy signal to the public. The point target helps anchor long term inflation expectation more effectively, while the tolerate band provides some flexibility to absorb temporary shocks. Giving the forward-looking nature of monetary

${ }^{2}$ The description of this section is based on the website of the Bank of Thailand. See:

https://www.bot.or.th/English/MonetaryPolicy/MonetPolicyKnowledge/Pages/default.aspx 
policy, the time horizon for targeting has expanded from quarterly to annual average which is better attuned with the 1-2 year time lag before the monetary policy gains its policy impact on the economy.

\section{Literature Review and Contributions}

This section reviews previous studies on the assessment of Thailand monetary policy and clarifies this paper's contributions. We confine the reviews to the empirical studies with the sample data covering the period after 2005, namely the period enough to assess the inflation targeting of Thailand that was initiated in May 2000. The number of the reviewed articles would, therefore, be quite limited. The literature can be classified into the studies of monetary policy rule and those of policy transmission effect on inflation.

Regarding the literature on monetary policy rule in Thailand, Hsing (2009) simply estimated monetary policy reaction functions for Thailand with the sample period from the first quarter of 1993 to the second quarter of 2007 as well as for Indonesia, Malaysia and the Philippines, and verified the existence of inflation-responsive rule in the contemporaneous manner. This study, however, focused only on the comparison of rules among four economies above, and did not imply any linkage with inflation targeting framework. Taguchi and Kato (2011) tried to evaluate the inflation targeting implementation for Thailand by examining its monetary policy rule with the sample period from the second quarter of 2000 to the fourth quarter of 2009 , together with the cases for Indonesia, Korea and the Philippines. By estimating a policy reaction function, the study identified the inflation-responsive but backwardlooking monetary policy rule for Thailand. As the more recent study, Lueangwilai (2012) also analyzed monetary policy implementation under the inflation targeting in Thailand during the period from June 2000 to June 2011 , by applying the Bayesian Maximum Likelihood estimation to a small, open economy model. The study considered exchange rate movement as a determinant factor of the policy rule and took into account the various types of the rule in the time horizon: contemporaneous, backward-looking and forward-looking. Its main finding was that the contemporaneous rule responding to inflation and exchange rate movement well characterized the policy rate set by the Bank of Thailand.

As for the studies of policy transmission effect on inflation, Taguchi and Kato (2011) again, by confirming the inflation-responsive but backward-looking monetary policy rule under the inflation targeting in Thailand, investigated its policy effect on inflation during the same period from the second quarter of 2000 to the fourth quarter of 2009, and could not find any significant impulse response of inflation rate to a monetary policy shock. As the more recent studies for Thailand, Phiromswad (2015) and Arwatchanakarn (2017) examined monetary policy transmission mechanism by using structural VAR model, and found a policy channel to price level and output, respectively. Since the sample period of Phiromswad (2015) is from the first quarter of 1999 to the fourth quarter of 2011 and the one of Arwatchanakarn (2017) is from the third quarter of 1997 to the fourth quarter of 2014, however, their studies are not necessarily linked with the adoption of inflation targeting framework in Thailand.

This study contributes to the reviewed literature above on the assessment of Thailand monetary policy as follows. First, this study updates the assessment of Thailand monetary policy with a focus on its inflation targeting by extending the sample period from the second quarter of 2000 (the starting time of inflation targeting) to the second quarter of 2017. In particular, covering the period after 2015 as the analytical sample is significant enough to evaluate the inflation targeting, since the Bank of Thailand transformed its framework in January 2015 from the range target of 0.5-3.0 percent to the point target at 2.5 percent with a band of \pm 1.5 percent to provide a clearer policy signal to the public as mentioned in Section 2. Any of studies in the aforementioned literature did not cover this critical period for assessing the inflation targeting. Second, this study combines the analysis of monetary policy rule with the one of its transmission effect to provide a comprehensive evaluation for the inflation targeting. In the reviewed literature, it was only Taguchi and Kato (2011) that combined two kinds of analyses, whereas the other studies dealt with them separately. In this sense, the major role of this study is to update (Taguchi and Kato, 2011) by including the new phase of the inflation targeting in Thailand as the sample period.

\section{Empirical Analyses}

This section conducts the empirical analyses in order to examine the monetary policy rule and its performance under inflation targeting framework focusing on Thailand. For examining the monetary policy rule, the study estimates the policy reaction function to see if the adoption of inflation targeting has been linked with an inflationresponsive monetary policy rule. The study then investigates further whether the monetary policy rule would actually have its transmission effect on inflation, through tracing the impulse responses of inflation rate to monetary policy shocks in VAR and SVAR models.

The analyses here sample the quarterly data running from the second quarter of 2000 to the second quarter of 2017 during which the Bank of Thailand has operated the inflation targeting and has also upgraded it. The source of all the data used for the subsequent estimations is the International Financial Statistics (IFS) of the international Monetary Fund (IMF). ${ }^{3}$ The analytical indicators are selected as follows: "Central Bank Policy Rate" for policy interest rate (denoted by por); "Consumer Prices Index $(2010=100)$ " for price index, which is transformed into its year-on-year change rate as inflation rate for the estimation $(\pi)$; "Gross Domestic Product (GDP), Volume, Seasonally Adjusted $(2010=100)$ )" for GDP, which is further processed into GDP gap (gap) by subtracting from the GDP a Hodrick-Prescott-filter of that series as a proxy of potential GDP level; and "National Currency per US Dollar, Period Average" for exchange rate, which is expressed as its year-on-year change rate (exr). The combination between policy interest rate and the other variables of inflation rate, GDP gap and exchange rate, are simply displayed in Figure 2. This observation itself does not tell us clear correlations and causalities in any combinations, and so should be statistically tested in the more sophisticated ways in the later sections. 
Table-1. Unit Root Test

\begin{tabular}{ccccc}
\hline \hline & MZa & MZt & MSB & MPT \\
\hline por & $-11.200 * *$ & $-2.361 * *$ & $0.210 * *$ & $2.206 * *$ \\
$\pi$ & $-33.932 * * *$ & $-4.107 * * *$ & $0.121 * * *$ & $0.756 * * *$ \\
$g a p$ & $-18.766 * * *$ & $-3.063 * * *$ & $0.163 * * *$ & $1.305 * * *$ \\
exr & $-31.299 * * *$ & $-3.947 * * *$ & $0.126 * * *$ & $0.807 * * *$ \\
\hline \hline \hline & $\mathrm{MZa}$ & $\mathrm{MZt}$ & $\mathrm{MSB}$ & $\mathrm{MPT}$ \\
\hline$d(\pi)$ & $-52.474 * * *$ & $-5.089 * * *$ & $0.096 * * *$ & $0.548 * * *$ \\
$d($ gap $)$ & $-33.291 * * *$ & $-4.063 * * *$ & $0.122 * * *$ & $0.786 * * *$ \\
$d($ exr $)$ & $-16.941 * * *$ & $-2.894 * * *$ & $0.170 * * *$ & $1.506 * * *$ \\
\hline \hline
\end{tabular}

Note: ***, ** denote the rejection of null hypothesis at the $99 \%$ and $95 \%$ level of significance. Sources: IFS of IMF

Before conducting the estimations below, we investigate the stationary property of the data for each variable, by employing the Ng-Perron unit root test ${ }^{4}$ on the null hypothesis that each variable has a unit root in the test equation including "intercept". This test constructs four test statistics: modified forms of Phillips and Perron (1988) statistics (MZa, MZt), the Bhargava (1986) statistic (MSB), and the Point Optimal statistic (MPT). Table 1 reports the test results for the data for all the indicators, i.e., policy interest rate (por) for its level data; and inflation rate $(\pi)$, GDP gap (gap) and exchange rate $(e x r)$ for their level and first difference data. The test rejected a unit root in all the data at the conventional level of significance by more than 95 percent, thereby their data showing stationary property. Thus their data are justified to be used for the subsequent estimations.

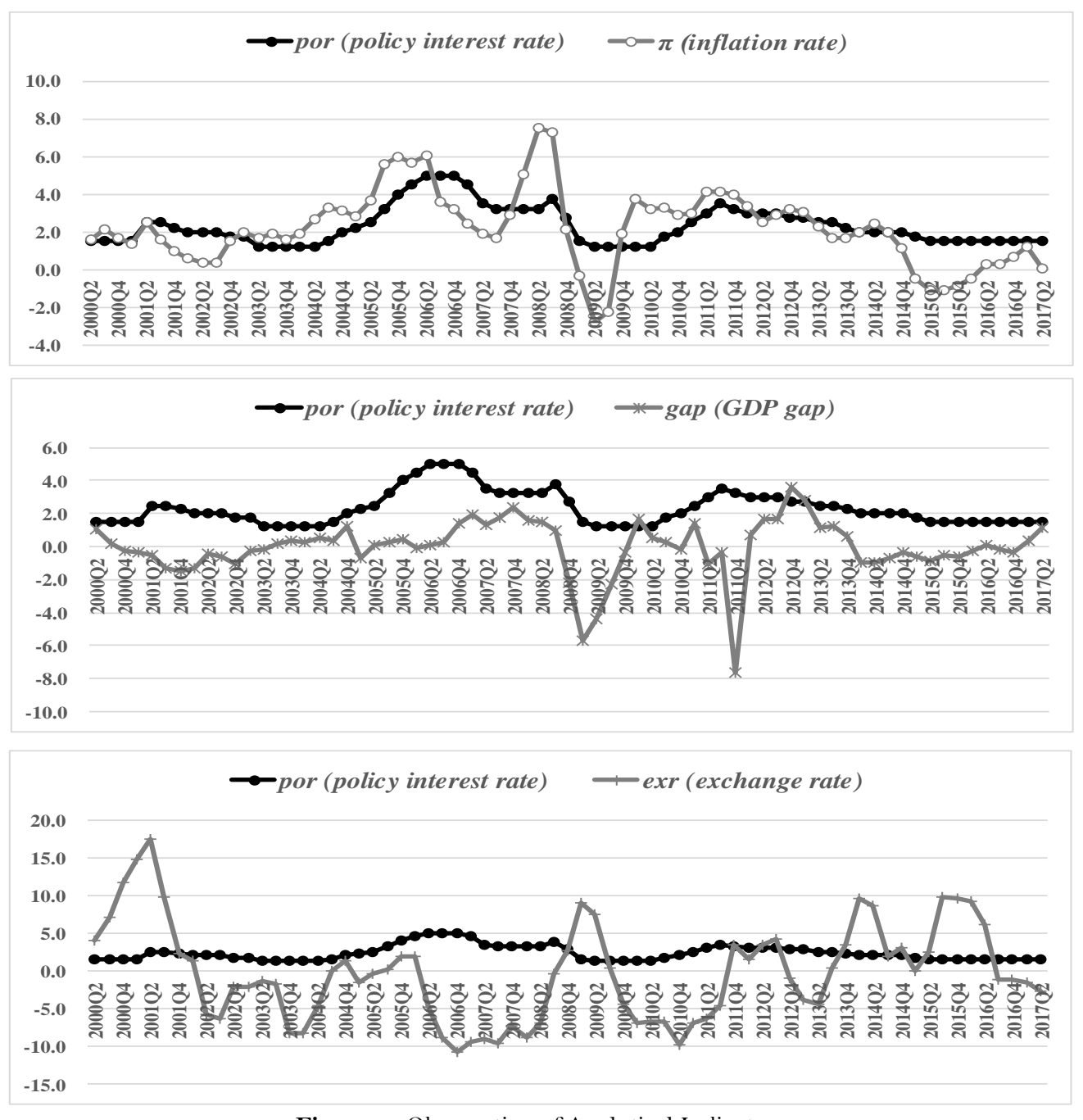

Source: IFS of IMF

Figure-2. Observation of Analytical Indicators

\subsection{Policy Reaction Function}

The policy reaction function is one of the useful analytical tools to describe a monetary policy rule in practices managed by a central bank. Its standard specification is that a central bank adjusts the nominal policy interest rate in response to the gaps between expected inflation and output, and their respective targets. It can be interpreted as a more generalized rule of the Taylor rule (see Taylor (1993)) - the simple backward-looking reaction function. The estimable policy reaction functions were presented for the first time by Clarida and Gertler (1997) for Bundesbank monetary policy, Clarida et al. (1998a) for the US monetary policy, and Clarida et al. (1998b) for monetary policies of two sets countries: the G3 (Germany, Japan, and the US) and the E3 (UK, France, and Italy).

\footnotetext{
${ }^{4} \mathrm{Ng}$ and Perron (2001) introduced a new unit root test, which used detrended data and a lag selection procedure that improved on previous methods.
} 
Among them, Clarida et al. (1998b) demonstrated the most comprehensive estimation of policy reaction functions. For estimating the G3 monetary policy rules, they took the forward-looking specification as the baseline and the backward-looking function as the alternative for their comparison, and they found that the G3 pursued forwardlooking rules, responding to anticipated inflation as opposed to lagged inflation. As for the E3 estimation, they added such explanatory terms as German interest rate and exchange rate in their functions, to examine how the constraints of the European Monetary System that collapsed in late 1992 influenced the E3 monetary policy rules.

This study applies the methodology of Clarida et al. (1998b) to estimate the policy reaction function for Thailand during the second period from quarter of 2000 to the second quarter of 2017 . The analysis employs both of forward-looking and backward-looking specifications for the estimation, since emerging market economies including Thailand may face the difficulties in forecasting inflation rate as Eichengreen (2002) suggested. In fact, the previous studies such as Taguchi and Kato (2011) and Lueangwilai (2012) identified backward-looking and contemporaneous rules for the Thailand monetary policy. The analysis also includes the exchange rate term as one of the monetary policy determinants, since emerging market economies including Thailand may fall into a "fear of floating" as Calvo and Reinhart (2002) suggested.

The original policy reaction function presented by Clarida et al. (1998b) is shown as the following Equation (1).

$$
\operatorname{por}_{t}^{*}=\bar{r}+\beta *\left(E\left[\pi_{t+n} \mid \Omega_{t}\right]-\pi^{*}\right)+\gamma *\left(E\left[y_{t} \mid \Omega_{t}\right]-y_{t}^{*}\right)
$$

where por $_{t}{ }^{*}$ is a target for the nominal short-term interest rate; $\bar{r}$ is the long-run equilibrium nominal interest rate; $\pi_{t+n}$ is the inflation rate at the period $t+n ; y_{t}$ is the real output, $\pi^{*}$ and $y_{t}{ }^{*}$ are respective bliss points for inflation and real output; $E$ is the expectation operator; and $\Omega$ is the information available to the central bank at the time when it sets the interest rate.

Equation (1) can be rewritten for empirical specification by defining $\alpha \equiv \bar{r}-\beta \pi^{*}$ and $g a p_{t} \equiv y_{t}-y_{t}{ }^{*}$, and by replacing the unobserved forecast variables with realized variables as follows.

$$
\text { por }_{t}^{*}=\alpha+\beta * \pi_{t+n}+\gamma * g a p_{t}+\varepsilon_{t}
$$

Where $\varepsilon_{t}$ is a linear combination of the forecast errors of inflation and real output. Then the Equation (2) is modified in accordance with our analytical concerns into the forward-looking specification in Equation (3) and the backward-looking specification in Equation (4) and the Equation (3) and (4) also include the exchange rate term, exr, as follows.

$$
\begin{array}{ll}
\operatorname{por}_{t}^{*}=\alpha+\beta * \pi_{t+n}+\gamma * \operatorname{gap}_{t}+\delta * \operatorname{exr}_{t}+\varepsilon_{t} & n=1,2,3 \text { and } 4 \\
\operatorname{por}_{t}^{*}=\alpha+\beta * \pi_{t-n}+\gamma * \operatorname{gap}_{t}+\delta * \operatorname{exr}_{t}+\varepsilon_{t} & n=0,1,2 \text { and } 3
\end{array}
$$

The Equation (3) and (4) are further modified for obtaining estimable equations since the central bank tends to conduct smooth changes in its policy interest rate in their practices. By assuming that the actual rate partially adjusts to the target as por $_{t}=(1-\rho) *$ por $_{t}{ }^{*}+\rho * \operatorname{por}_{t-1}+v_{t}$ where $\rho$ is the degree of smoothing with $0<\rho<$ 1 and $v$ is the disturbance term, Equations (3) and (4) can be further rewritten into Equation (5) and (6) as follows.

$$
\begin{aligned}
& \text { por }_{t}=(1-\rho) \alpha+(1-\rho) \beta * \pi_{t+n}+(1-\rho) \gamma * \operatorname{gap}_{t}+(1-\rho) \delta * \operatorname{exr}_{t}+\rho * r_{t-1}+\varepsilon_{t} \\
& \text { por }_{t}=(1-\rho) \alpha+(1-\rho) \beta * \pi_{t-n}+(1-\rho) \gamma * \operatorname{gap}_{t}+(1-\rho) \delta * \operatorname{exr}_{t}+\rho * r_{t-1}+\varepsilon_{t}
\end{aligned}
$$

For the technique to estimate the parameter vector $[\alpha, \beta, \gamma, \delta, \rho]$, we adopt generalized method of moments, since the equations above entail endogeneity problem in that the policy interest rate may also affect explanatory variables. The instrumental set includes one- and two-quarter lagged values of inflation rate $\pi$, GDP gap gap, and exchange rate $e x r$, in the estimation Equation (5) and (6). The J-statistic implies that these instrumental variables are valid in the sense that the over-identifying restrictions cannot be rejected in the models above except for the case of $\pi_{t+4}$ (see Table 2 ).

Table 2 reports the estimation outcomes of policy reaction functions in two kinds of specifications: the forwardlooking specification in the Equation (5) and the backward-looking specification in the Equation (6). Based on the estimated short-term coefficients in the Equations of (5) and (6) the long-term coefficients are worked out in the Equations of (3) and (4) which are displayed in the lower part of each table. When we focus on the long-term coefficients, the cases of $\pi_{t+2}$ and $\pi_{t+3}$ are excluded from their calculations, since the degree of smoothing $\rho$ is beyond unity, which is against our expectation. It is in the cases of $\pi_{t+1}$ and $\pi_{t}$ that the coefficient of inflation $\beta$ is positively discernable at the conventional significant level. We herein identify the case of $\pi_{t+1}$, the forward-looking specification with one quarter ahead, as the most suitable specification for the Thailand policy reaction function, since the inflation coefficient has the higher significance by more than 99 percent and its magnitude is large enough to exceed unity by 1.966. In that case, we also confirm the significance at 95 percent level in the coefficient of exchange rate $\delta$, but not in the coefficient of GDP gap. 
Table-2. Policy Reaction Functions

\begin{tabular}{|c|c|c|c|c|}
\hline Forward-looking & $\pi_{t+1}$ & $\pi_{t+2}$ & $\pi_{t+3}$ & $\pi_{t+4}$ \\
\hline$(1-\rho)^{*} \alpha$ & $\begin{array}{l}-0.121 \\
(-0.745)\end{array}$ & $\begin{array}{c}-0.456 \\
(-1.569)\end{array}$ & $\begin{array}{c}-0.423 \\
(-1.197)\end{array}$ & $\begin{array}{c}0.688 \\
(0.983)\end{array}$ \\
\hline$(1-\rho) * \beta$ & $\begin{array}{c}0.143 * * * \\
(3.820)\end{array}$ & $\begin{array}{l}0.080 * \\
(1.904)\end{array}$ & $\begin{array}{l}0.077 * \\
(1.914)\end{array}$ & $\begin{array}{c}-0.044 \\
(-1.338)\end{array}$ \\
\hline$(1-\rho) * \gamma$ & $\begin{array}{c}0.001 \\
(0.044)\end{array}$ & $\begin{array}{c}0.053 \\
(0.644)\end{array}$ & $\begin{array}{c}0.110 \\
(1.428)\end{array}$ & $\begin{array}{c}0.118 \\
(1.441)\end{array}$ \\
\hline$(1-\rho) * \delta$ & $\begin{array}{c}0.017 * * \\
(2.392)\end{array}$ & $\begin{array}{c}0.014 \\
(1.104)\end{array}$ & $\begin{array}{c}0.015 \\
(1.327)\end{array}$ & $\begin{array}{c}-0.006 \\
(-0.304)\end{array}$ \\
\hline$\rho$ & $\begin{array}{c}0.927 * * * \\
(12.051)\end{array}$ & $\begin{array}{c}1.150 * * * \\
(10.094)\end{array}$ & $\begin{array}{c}1.138 * * * \\
(8.180)\end{array}$ & $\begin{array}{c}0.721 * * * \\
(2.728)\end{array}$ \\
\hline$J$-statistics & $\begin{array}{l}2.802 \\
(0.246)\end{array}$ & $\begin{array}{c}2.359 \\
(0.307)\end{array}$ & $\begin{array}{c}2.935 \\
(0.230)\end{array}$ & $\begin{array}{l}4.622 * \\
(0.099)\end{array}$ \\
\hline \multicolumn{5}{|c|}{ Long-term Coefficients } \\
\hline$\alpha$ & -1.667 & - & - & 2.470 \\
\hline$\beta$ & $1.966 * * *$ & - & - & -0.160 \\
\hline$\gamma$ & 0.027 & - & - & 0.426 \\
\hline$\delta$ & $0.246 * *$ & - & - & -0.023 \\
\hline Backward-looking & $\pi_{t}$ & $\pi_{t-1}$ & $\pi_{t-2}$ & $\pi_{t-3}$ \\
\hline$(1-\rho)^{*} \alpha$ & $\begin{array}{c}0.043 \\
(0.195)\end{array}$ & $\begin{array}{c}0.107 \\
(0.698)\end{array}$ & $\begin{array}{l}0.267 * \\
(1.795)\end{array}$ & $\begin{array}{c}0.555 * * \\
(2.204)\end{array}$ \\
\hline$(1-\rho) * \beta$ & $\begin{array}{c}0.089 * * \\
(2.270)\end{array}$ & $\begin{array}{c}0.033 \\
(0.897)\end{array}$ & $\begin{array}{c}0.050 \\
(0.945)\end{array}$ & $\begin{array}{c}0.081 \\
(1.574)\end{array}$ \\
\hline$(1-\rho) * \gamma$ & $\begin{array}{c}-0.010 \\
(-0.269)\end{array}$ & $\begin{array}{c}0.029 \\
(0.520)\end{array}$ & $\begin{array}{c}0.068 \\
(1.453)\end{array}$ & $\begin{array}{c}0.153 * * \\
(2.094)\end{array}$ \\
\hline$(1-\rho) * \delta$ & $\begin{array}{c}0.009 \\
(1.049)\end{array}$ & $\begin{array}{c}0.003 \\
(0.386)\end{array}$ & $\begin{array}{c}0.003 \\
(0.311)\end{array}$ & $\begin{array}{c}0.006 \\
(0.474)\end{array}$ \\
\hline$\rho$ & $\begin{array}{c}0.900 * * * \\
(7.125)\end{array}$ & $\begin{array}{c}0.922 * * * \\
(12.467)\end{array}$ & $\begin{array}{c}0.834 * * * \\
(8.894)\end{array}$ & $\begin{array}{c}0.689 * * * \\
(4.743)\end{array}$ \\
\hline$J$-statistics & $\begin{array}{c}2.555 \\
(0.278)\end{array}$ & $\begin{array}{c}2.201 \\
(0.332)\end{array}$ & $\begin{array}{c}2.562 \\
(0.227)\end{array}$ & $\begin{array}{c}0.453 \\
(0.797)\end{array}$ \\
\hline \multicolumn{5}{|c|}{ Long-term Coefficients } \\
\hline$\alpha$ & 0.440 & 1.387 & $1.612 *$ & $1.789 * *$ \\
\hline$\beta$ & $0.895 * *$ & 0.430 & 0.302 & 0.262 \\
\hline$\gamma$ & -0.107 & 0.380 & 0.415 & $0.493 * *$ \\
\hline$\delta$ & 0.092 & 0.050 & 0.020 & 0.020 \\
\hline
\end{tabular}

Note: ******* $*$ denote the rejection of null hypothesis at the $99 \%, 95 \%$ and $90 \%$ level of significance.

Sources: IFS of IMF

We interpret the estimation results above as follows. First, the Bank of Thailand appears to have adopted the inflation-responsive and forward-looking (one quarter ahead) monetary policy rule under its inflation targeting framework. This finding is much different from the previous studies such as Taguchi and Kato (2011) and Lueangwilai (2012) that identified backward-looking and contemporaneous rules for Thailand monetary policy. The difference might come from the fact that this study's estimation covers the period after 2015 when the Bank of Thailand has upgraded its inflation targeting framework by transforming it from range target to point target to provide a clearer policy signal to the public as mentioned in Section 2. Second, the Thailand inflation-responsive rule is countercyclical enough to affect real interest rate, since the magnitude of the response to inflation is more than unity. This countercyclical rule seems to be similar to those of advanced economies; the magnitude of the Bank of Thailand in this study, 1.966, is comparable to those of the Bundesbank (1.31), the Bank of Japan (2.04) and the Federal Reserve System in USA (1.79). This study's magnitude is also consistent with that of the previous study, for instance, 1.969 in Taguchi and Kato (2011). Third, the Thailand monetary policy rule is also responsive to exchange rate movement. It might reflect the fact that the Bank of Thailand has still taken a role to avoid the excess of volatility of the value of the baht, particularly resulting from speculative capital flow, through the intervention in foreign exchange market, even under the inflation targeting regime. ${ }^{5}$ The exchange-rate responsive rule seems to be related to the problem of "fear of floating" in emerging market economies including Thailand. This rule is also consistent with the one that Lueangwilai (2012) described as responding to inflation and exchange rate movement. Lastly, it should be noted that the adjustment speed of a policy interest rate toward its target rate in the operation of the Bank of Thailand is slower than those in central banks in advanced economies. The smoothing speed $\rho$ for Thailand is 0.927 in "quarterly" base, whereas the "monthly" smoothing speed is 0.91 for the Bundesbank; 0.93 for the Bank of Japan, and 0.92 for the Federal Reserve System, respectively. The Thailand adjustment speed is, thus, about one-third of those in the G3 countries.

To sum up, the Thailand monetary policy rule under the inflation targeting is characterized as an inflation- and exchange-rate- responsive rule with forward-looking manner (one quarter ahead), which is countercyclical against inflation in the long run, but is accompanied with slow adjustment toward a target policy rate. 


\subsection{Policy Transmission Effect on Inflation}

This section examines whether the Thailand monetary policy rule would actually have its transmission effect on inflation, through tracing the impulse responses of inflation rate to monetary policy shocks in VAR and structural VAR (SVAR) models. The ordinary VAR model was traditionally used for examining the effects of monetary policy shocks, for instance, by Christiano et al. (1996). It was also applied to investigating economic impacts of the Thailand monetary policy shocks (e.g., Taguchi and Kato (2011)). Then, the VAR model has been developed into the SVAR model under the assumption that the concerned variables should be contemporaneously and dynamically interdependent. The SVAR has become more popular than the ordinary VAR, since theoretical and empirical grounds can be incorporated for imposing the restrictions on the model. Christiano et al. (1999) for instance, applied the SVAR to examining the effects of monetary policy shocks, and Phiromswad (2015) and Arwatchanakarn (2017) also utilized the SVAR for the analyses of Thailand monetary policy.

This study adopts the same four variables as in the policy reaction function for the model construction: policy interest rate (por), inflation rate $(\pi)$, GDP gap (gap) and exchange rate $(e x r)$, since the variables here should be consistent with those used in the policy reaction function so that the implementation and performance of the Thailand inflation targeting can be simultaneously examined. The variables in this study are confined to the four indicators above, also because the purpose of this study is not to deal directly with the transmission channels and mechanisms inside of the Thailand monetary markets. The study also uses the modified version of variables through first difference except for policy interest rate: $d(\pi), d(g a p)$ and $d($ exr $)$, in order to investigate a "marginal" effect of monetary policy shocks

We start to specify an equation for the ordinary VAR estimation in the following way.

$$
y_{t}=\mu+V y_{t-1}+\varepsilon_{t}
$$

Where $y_{t}$ is a column vector of the endogenous variables with year $t$, i.e., $y_{t}=\left(\text { por }_{t} \pi_{t} \operatorname{gap}_{t} \operatorname{exr}_{t}\right)^{\prime}$ for examining an ordinary policy transmission effect, and $y_{t}=\left(\operatorname{por}_{t} d\left(\pi_{t}\right) d\left(\operatorname{gap}_{t}\right) d\left(\operatorname{exr}_{t}\right)\right)^{\prime}$ for examining a marginal transmission effect; $\mu$ is a constant vector; $V$ is a coefficient matrix; $y_{t-1}$ is a vector of the lagged endogenous variables; and $\varepsilon_{i t}$ is a vector of the random error terms in the system. The lag length $(-1)$ is selected by the Schwarz information criterion with maximum lag being equal to (-2) under the limited number of observations from the second quarter of 2000 to the second quarter of 2017.

Based on the VAR model estimation above, we examine the impulse responses of inflation rate to the shock of policy interest rate in terms of ordinary and marginal transmission effects. In examining the impulse response, the structural policy shock should be identified by applying the SVAR model under the assumption of the contemporaneous relationship among the sampled four variables. For that purpose, there are several approaches to impose the restrictions to identify structural shocks: short-run restriction and long-run restriction. This study, as in Christiano et al. (1999) adopts the short-run restriction by assuming the existence of time-lag for policy reaction so that policy rate can keep a recursive linkage with inflation rate, GDP gap and exchange rate. The impulse responses of inflation to the structural shock of policy rate under the SVAR are also presented together with the ordinary impulse responses.

Table 3 and Figure 3 respectively report the estimation outcomes of VAR model and the impulse responses of inflation rate to the ordinary and structural shocks of policy rate with 95 percent error bands over a 8-quarter horizon, in terms of ordinary and marginal transmission effects. According to the ordinary transmission effect, inflation rate does not respond significantly to the policy-rate shock in the VAR model, and it responds even positively to the structural shock of policy-rate during the initial four quarters under the SVAR model. As for the marginal transmission effect, inflation rate responds negatively to the policy-rate shock from the beginning quarter in the VAR model and from the fifth quarter in the SVAR model. The results of impulse response analyses, therefore, imply that the Thailand monetary policy under inflation targeting has only a marginal transmission effect on inflation. It might be probably because the Thailand monetary policy rule is accompanied with slow adjustment toward a target policy rate, although the rule is found to be inflation-responsive, forward-looking and countercyclical against inflation.

Table-3. VAR Model Estimation

\begin{tabular}{|c|c|c|c|c|}
\hline & por & $\pi$ & gap & exr \\
\hline por $(-1)$ & $\begin{array}{c}0.823 * * * \\
(15.049)\end{array}$ & $\begin{array}{c}-0.186 \\
(-1.034)\end{array}$ & $\begin{array}{c}0.063 \\
(0.268)\end{array}$ & $\begin{array}{c}-0.710 \\
(-1.229)\end{array}$ \\
\hline$\pi(-1)$ & $\begin{array}{c}0.090 * * \\
(3.116)\end{array}$ & $\begin{array}{c}0.795 * * * \\
(8.322)\end{array}$ & $\begin{array}{c}-0.063 \\
(-0.507)\end{array}$ & $\begin{array}{c}0.337 \\
(1.102)\end{array}$ \\
\hline $\operatorname{gap}(-1)$ & $\begin{array}{c}0.011 \\
(0.407)\end{array}$ & $\begin{array}{c}0.114 \\
(1.236)\end{array}$ & $\begin{array}{c}0.456 * * * \\
(3.738)\end{array}$ & $\begin{array}{c}0.155 \\
(0.522)\end{array}$ \\
\hline $\operatorname{exr}(-1)$ & $\begin{array}{c}0.003 \\
(0.535)\end{array}$ & $\begin{array}{l}-0.042 * \\
(-1.735)\end{array}$ & $\begin{array}{c}-0.040 \\
(-1.252)\end{array}$ & $\begin{array}{c}0.847 * * * \\
(10.829)\end{array}$ \\
\hline$C$ & $\begin{array}{l}0.210 * \\
(1.881)\end{array}$ & $\begin{array}{c}0.866 * * \\
(2.349)\end{array}$ & $\begin{array}{c}-0.040 \\
(-0.083)\end{array}$ & $\begin{array}{c}0.772 \\
(0.653)\end{array}$ \\
\hline $\operatorname{adj} . R^{\wedge} 2$ & 0.883 & 0.676 & 0.225 & 0.682 \\
\hline
\end{tabular}


[Marginal Transmission Effect]

\begin{tabular}{|c|c|c|c|c|}
\hline & por & $d(\pi)$ & $d(g a p)$ & $d($ exr $)$ \\
\hline $\operatorname{por}(-1)$ & $\begin{array}{c}0.949 * * * \\
(22.942)\end{array}$ & $\begin{array}{c}-0.262 * * \\
(-1.981)\end{array}$ & $\begin{array}{c}-0.144 \\
(-0.717)\end{array}$ & $\begin{array}{c}0.089 \\
(0.199)\end{array}$ \\
\hline$d(\pi)(-1)$ & $\begin{array}{c}0.121 * * * \\
(3.439)\end{array}$ & $\begin{array}{c}0.371 * * * \\
(3.277)\end{array}$ & $\begin{array}{c}0.199 \\
(1.161)\end{array}$ & $\begin{array}{c}-0.142 \\
(-0.372)\end{array}$ \\
\hline$d($ gap $)(-1)$ & $\begin{array}{c}0.007 \\
(0.288)\end{array}$ & $\begin{array}{c}0.039 \\
(0.461)\end{array}$ & $\begin{array}{c}-0.329 * * \\
(-2.528)\end{array}$ & $\begin{array}{c}0.098 \\
(0.339)\end{array}$ \\
\hline$d(e x r)(-1)$ & $\begin{array}{c}0.000 \\
(0.014)\end{array}$ & $\begin{array}{c}-0.045 \\
(-1.208)\end{array}$ & $\begin{array}{c}-0.068 \\
(-1.187)\end{array}$ & $\begin{array}{c}0.323 * * \\
(2.529)\end{array}$ \\
\hline$C$ & $\begin{array}{c}0.118 \\
(1.127)\end{array}$ & $\begin{array}{l}0.588 * \\
(1.744)\end{array}$ & $\begin{array}{c}0.325 \\
(0.636)\end{array}$ & $\begin{array}{c}-0.289 \\
(-0.254)\end{array}$ \\
\hline adj. $R^{\wedge} 2$ & 0.886 & 0.195 & 0.050 & 0.042 \\
\hline
\end{tabular}

Note: ***, **, * denote the rejection of null hypothesis at the $99 \%, 95 \%$ and $90 \%$ level of significance. Sources: IFS of IMF

[Ordinary Transmission Effect]
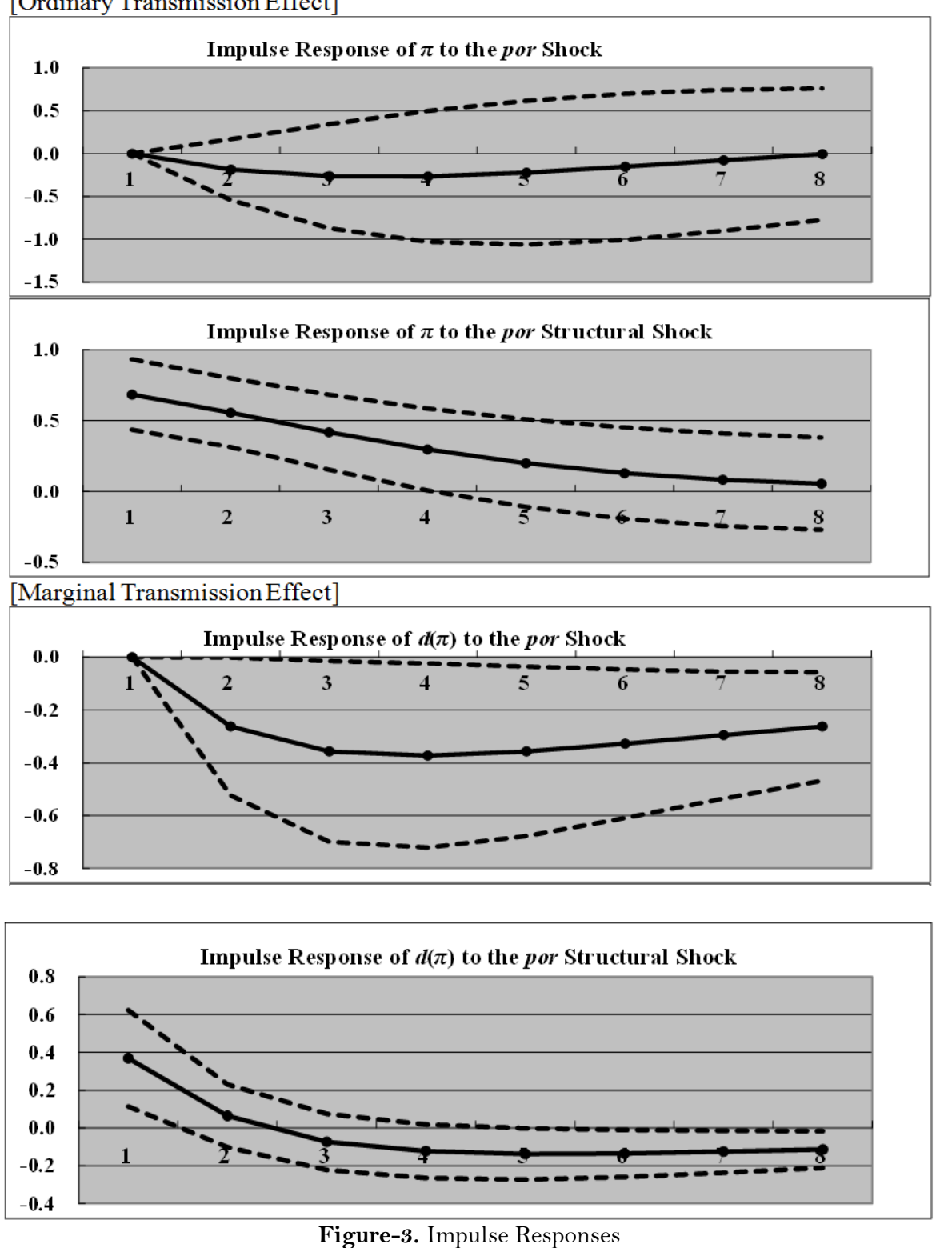

Note: The dotted lines denote a 95 percent error band over 8-year horizons.

Source: IFS of IMF

\section{Concluding Remarks}

This article reviewed the Thailand monetary policy rule and its performance under the adoption of inflation targeting regime since 2000. The study estimated the policy reaction function to see if the inflation targeting has been linked with an inflation-responsive monetary policy rule, and investigated whether the monetary policy rule would actually have its transmission effect on inflation, through tracing the impulse responses of inflation rate to monetary policy shocks in vector autoregressive (VAR) and structural VAR models. The study contributed to the literature by updating the assessment of the Thailand monetary policy through covering the period after 2015, when the Bank of Thailand has upgraded its inflation targeting framework by transforming it from range target to point target to provide a clearer policy signal to the public.

The main findings were as follows. First, the estimation outcomes of the policy reaction function showed that the Thailand monetary policy rule under the inflation targeting is characterized as an inflation- and exchange-rateresponsive rule with forward-looking manner. The identified progress in the Thailand monetary policy toward forward-looking rule might reflect the upgrading in the inflation targeting regime from range target to point target since 2015. Second, the estimation results also demonstrated that the Thailand monetary policy rule is countercyclical against inflation in the long run, but is accompanied with slow adjustment toward a target policy 
rate. Third, the results from the impulse response analyses suggested that the Thailand monetary policy under the inflation targeting has only a marginal transmission effect on inflation probably due to the slow adjustment of policy rate.

\section{References}

Arwatchanakarn, P., 2017. Structural vector autoregressive analysis of monetary policy in Thailand. Sociology Study, 7(3): 13 3-145. View at Google Scholar | View at Publisher

Bernanke, B.S., T. Laubach, F.S. Mishkin and A.S. Posen, 1999. Inflation targeting: Lessons from the international experience. Princeton: Princeton University Press.

Bernanke, B.S. and F.S. Mishkin, 1997. Inflation targeting: A new framework for monetary policy? Journal of Economic Perspectives, 11(2): 97-1 16. View at Google Scholar

Bhargava, A., 1986. On the theory of testing for unit roots in observed time series. Review of Economic Studies, 53(3): 369-384. View at Google Scholar $\mid$ View at Publisher

Calvo, G. and C. Reinhart, 2002. Fear of floating. Quarterly Journal of Economics, 117(2): 379-408. View at Google Scholar

Christiano, L., M. Eichenbaum and C. Evans, 1996. The effects of monetary policy shocks: Evidence from the flows of funds. Review of Economics and Statistics, 78(1): 16-34. View at Google Scholar $\mid$ View at Publisher

Christiano, L., M. Eichenbaum and C. Evans, 1999. Monetary policy shocks: What have we learned and to what end. In J.B. Taylor and M. Woodford (Eds.) Handbook of macroeconomics. North Holland: Elsevier Science, 1A: 65-148.

Clarida, R., J. Gali and M. Gertler, 1998a. Monetary policy rules and macroeconomic stability: Theory and some evidence. NBER (National Bureau of Economic Research) Working Paper Series, No. 6442.

Clarida, R., J. Gali and M. Gertler, 1998b. Monetary policy rules in practice: Some international evidence. European Economic Review, 42(6): 1033-1067.

Clarida, R. and M. Gertler, 1997. How the Bundesbank conducts monetary policy. In C. Romer and D. Romer (Eds.) Reducing inflation. University of Chicago Press. pp: $363-412$.

Eichengreen, B., 2002. Can emerging markets float? Should they inflation target? Working Paper (Banco Central do Brazil), No.36.

Gagnon, J.E. and J. Ihrig, 2004. Monetary policy and exchange rate pass-through. International Journal of Finance and Economics, 9(4): 315-338. View at Google Scholar

Hsing, Y., 2009. Is the monetary policy rule responsive to exchange rate changes? The case of Indonesia, Malaysia, the Philippines, and Thailand. International Review of Economics, 56(2): 123-132. View at Google Scholar | View at Publisher

Ito, T. and T. Hayashi, 2004. Inflation targeting in Asia. Occasional Paper (Hong Kong Institute for Monetary Research), No. 1.

Lin, S. and H. Ye, 2009. Does inflation targeting make a difference in developing countries?. Journal of Development Economics, 89(1): 118123. View at Google Scholar | View at Publisher

Lueangwilai, K., 2012. Monetary policy rules and exchange rate uncertainty: A structural investigation in Thailand. Procedia Economics and Finance, 2: 325-334. View at Google Scholar | View at Publisher

Mishkin, F.S., 2000. Inflation targeting in emerging market countries. American Economic Review, 90(2): 105-109. View at Google Scholar $\mid$ View at Publisher

Mishkin, F.S., 2004. Can inflation targeting work in emerging market countries? NBER (National Bureau of Economic Research) Working Paper Series, No. 10646.

Mishkin, F.S. and A.S. Posen, 1998. Inflation targeting: Lessons from four countries. NBER (National Bureau of Economic Research) Working Paper Series, No. 6126

Mishkin, F.S. and K. Schmidt-Hebbel, 2007. Does inflation targeting make a difference? NBER (National Bureau of Economic Research) Working Paper Series, No. 12876.

$\mathrm{Ng}$, S. and P. Perron, 2001. Lag length selection and the construction of unit root tests with good size and power. Econometrica, 69(6): 1519-1554. View at Google Scholar $\mid$ View at Publisher

Phillips, P. and P. Perron, 1988. Testing for unit root in time series regression. Biometrika, 75(2): 335-346. View at Google Scholar $\mid$ View at Publisher

Phiromswad, P., 2015. Measuring monetary policy with empirically grounded restrictions: An application to Thailand. Journal of Asian Economics, 38: 104-1 13. View at Google Scholar | View at Publisher

Taguchi, H. and C. Kato, 2011. Assessing the performance of inflation targeting in East Asian economies. Asian-Pacific Economic Literature, 25(1): 93-102. View at Google Scholar | View at Publisher

Taylor, J.B., 1993. Discretion versus policy rules practice. Carnegie-Rochester Conference on Public Policy, 39: 195-214. 